Vesna Požgaj Hadži*

Tatjana Balažic Bulc ${ }^{* *}$

University of Ljubljana
UDK 81Šuštaršič R.:811.163.6'34

DOI: 10.4312/linguistica.57.1.13-22

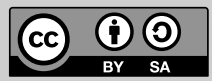

\title{
RASTISLAV ŠUŠTARŠIČ AND CURRENT ISSUES OF STANDARD SLOVENE LANGUAGE
}

\section{INTRODUCTION}

Language from the inside and language from the outside are two different approaches to the study of language. The first (native) language is most commonly studied through the view from the inside, which also applies to the studies of the standard Slovene language. However, the view from the outside, i.e. the view from the position of a foreign/ second language enables new and different understandings of language. One of scientific and research methods offering such a view is contrastive linguistics, which was used in the research carried out by Rastislav Šuštaršič, who we dedicate this paper to.

Contrastive studies of languages in contact have a rich tradition in Croatia, since they started back in the 1960s with the studies of Croatian (Serbo-Croatian) and foreign languages conducted under the supervision of R. Filipović, the doyen of contrastive linguistics, in today's Institute of linguistics at the Faculty of Philosophy, University of Zagreb. Up until the 1990s these studies were associated with three main themes: contrastive analysis, languages in contact, and a series of small phraseological dictionaries of Croatian and foreign languages. The synthesis of these studies is represented by a collection of papers (Filipović 1985; Filipović/Bratanić 1990; Ivir/Kalogjera 1991) where the authors deal with synchronic and diachronic studies of languages in contact at all language levels (phonetic and phonological, morphological, syntactic, lexical, phraseological, pragmatic, sociolinguistic, and so on). When it comes to the phonetic and phonological level, which is of interest to us in this paper, we should emphasize the Zagreb Phonetic School. Within this school numerous authors (P. Guberina, I. Škarić, B. Vuletić, M. Pozojević-Trivanović, D. Horga, V. Josipović, N. Desnica-Žerjavić et al.) investigated, both theoretically and experimentally, the system of phonetic errors in foreign languages in comparison with Croatian (cf. Požgaj Hadži/Balažic Bulc 2012: 15-19). As opposed to Croatia, contrastive linguistics in Slovenia did not become a common approach until as late as the 1980s, when papers on Slovene-(Serbo)Croatian contrastivity emerged. In these papers authors like V. Kalenić, J. Dular and others identify the similarities and differences between language systems and underline possible errors, while neglecting the analysis of errors. Experimental studies of different language levels of the (Serbo)Croatian and Slovene languages, one of which is phonetic and phonological, started in the mid-1980s within the projects of the Scientific

* vesna.hadzi@guest.arnes.si

**tatjana.balazic-bulc@guest.arnes.si 
Research Institute of the Faculty of Arts at the University of Ljubljana (Požgaj Hadži 2002: 25-33). In the second half of the 1990s they expanded to sociolinguistic and corpus themes ( $c f$. Požgaj Hadži/Balažic Bulc 2012: 17-21).

It is interesting to note that phonetic and phonological levels have always been neglected, or even omitted, in contrastive studies of languages in contact. In contrast to the studies of other language levels (morphological, syntactic, lexical), a series of experimental limitations is linked to phonetic and phonological levels, especially related to spoken language. Taking into consideration the learning and teaching of foreign or second languages, and even the first language (especially its pronunciation or error correction), not enough attention was given to the phonetic level for a number of reasons. For example, it is the most difficult part of language learning, communication is possible despite bad pronunciation, and numerous teachers have never mastered pronunciation of the language they teach ( $c f$. Požgaj Hadži et al. 2007: 97-98).

\section{SLOVENE-CROATIAN PHONETIC AND PHONOLOGICAL CONTRAS- TIVE RESEARCH}

A lack of systematic research at the phonetic and phonological level of the Croatian and Slovene languages, together with insufficient equipment for such research at the Faculty of Arts in Ljubljana, encouraged us to start working in teams on the two projects based on The Agreement on Slovene-Croatian Bilateral Cooperation in the Field of Science and Technology, as well as Slovene-Croatian Phonetic and Phonological Relations (2000-2002) and Croatian and Slovene in Psycholinguistic and Sociolinguistic Contact (2004-2005). The partner institutions within these projects include the Faculty of Arts, University of Ljubljana and the Faculty of Philosophy, University of Zagreb, with the two project leaders of D. Horga from the Department of Phonetics in Zagreb and V. Požgaj Hadži from the Department of Slavistics in Ljubljana, along with many other researchers. ${ }^{1}$ In addition, the Department of Phonetics in Zagreb celebrated its 50th anniversary in 2014; hence it has a rich tradition, especially in scientific and research work, which was from the very beginning both experimental and interdisciplinary. In contrast, there is no Department of Phonetics at the Faculty of Arts in Ljubljana; instead, the courses related to phonetics and phonology are taught at different departments, one of the most prominent being the Department of English, where R. Šuštaršič taught different courses on general and English phonetics and phonology, contrastive and acoustic phonetics, speech sound acquisition, and more. The

1 The researchers from Zagreb were mainly from the Department of Phonetics, namely, J. Bakran, I. Ivas, N. Lazić, M. Liker, E. Pletikos, I. Škarić, G. Varošanec-Škarić; but also N. Desnica-Žerjavić from the Department of Romance languages and literature; V. Erdeljac from the Department of Linguistics and V. Josipović from the Department of English Language and Literature. The researchers from Ljubljana were from different departments: S. Komar and R. Šuštaršič from the Department of English, J. Markič and P. Vitez from the Department of Romance Languages and Literatures, H. Tivadar from the Department of Slovene Studies and T. Balažic Bulc and E. Premk from the Department of Slavistics. 
above-mentioned projects are significant, because of the network of researchers from different departments at the two institutions, the exchange of experiences, and above all, the joint work on particular research topics, for which we mainly used the equipped laboratories at the Department of Phonetics in Zagreb.

\subsection{Slovene-Croatian Phonetic and Phonological Relations}

As was already emphasized, there was no systematic research in Slovenia related to the phonetic and phonological relations of the Croatian and Slovene language until the year 2000; therefore, we wanted to explore these issues further within three main themes of the first bilateral project (2000-2002), entitled Slovene-Croatian Phonetic and Phonological Relations.

Within the first theme - describing the phonetic and phonological features of the Croatian and Slovene languages separately and then comparing them - the following relations were observed: a) the previous phonological descriptions of Croatian and Slovene ${ }^{2}$ were systematically and critically reviewed and a potentially new description was proposed; b) the previous acoustic descriptions of Croatian and Slovene were compared and new segments which were not completely described were added (e.g. prosody); c) the fluctuations in standard prosody were investigated, specifically, the system of four pitch accents in Croatian and the dynamic and tonemic accentuation in Slovene; d) the system of intonation nucleus was explored at the level of sentence and discourse, and e) the relationship between lexical and phonetic words was investigated in connected speech. Within the second theme we observed a contact between two languages in the process of learning Croatian, in particular when Slovene or Croatian native speakers learn it, in the following two ways: a) by examining the system of phonetic errors of two languages when they get in contact in different ways, whether it is learnt or imitated experimentally; and b) by investigating the ways of phonetic and phonological adaptation of foreign proper names in both languages. Within the third theme, using the same theoretical basis as within the second, we observed the transparency of Croatian and Slovene at the phonetic level in English and French, by exploring how students who learn either English or French make errors considering also their first language - Slovene or Croatian. These two error systems were compared by measuring acoustic parameters, not only auditory, which was the common approach before this.

The value of the project lay in the fact that each of these two studied languages were observed both from the inside and from the outside. Namely, from the theoretical perspective the view from the outside, i.e. from the perspective of the other language, as was already indicated in the introduction, enables new and different understanding of language compared to the perspective when it is only viewed from the inside. For that purpose, the following objectives were proposed for this project: a) a comparative description of phonological systems of Croatian and Slovene; b) a comparative acoustic

2 The list of topics is given only for informational purposes, and thus we do not cite literature for each topic separately. 
description of the standard phonetic system of Slovene and Croatian (sonants, word accent, sentence prosody, the features of spontaneous speech); c) sociolinguistic valorisation of standard elements in Croatian and Slovene and determination of value of orthoepic "errors;" d) a description of the phonetic errors of Croatian speakers who are in contact with the Slovene language and Slovene speakers in contact with Croatian; and e) a description of the phonetic errors of Croatian and Slovene speakers learning English and French. In order to accomplish these aims, the spoken material was collected in public electronic media or recorded in studios and experimental settings. The research studies were conducted in Slovenia for the Slovene language and in Croatia for the Croatian language, while the data were processed using speech analysis software depending on the experimental equipment used in the project.

\subsection{Croatian and Slovene in Psycholinguistic and Sociolinguistic Contact}

The second project (2004-2005), entitled Croatian and Slovene in Psycholinguistic and Sociolinguistic Contact, continued the work on some of the open issues, and primarily the analyses of the collected spoken material. ${ }^{3}$

What is especially emphasized in this project is the fact that the research into these two closely related and neighbouring languages, Croatian and Slovene, is associated with the development of a multilingual European area, which is characterized by the coexistence and equality of languages. In other words, we researched both the speech of two languages in contact and their relations with French, English and Spanish (the latter was not included in the first project). In terms of the systematic characteristics, we provided a detailed description of phonetic segments and their postulates in spoken language use, as well as a description and systematic analysis of some difficulties in their realisation in particular languages as first/foreign/second from the sociolinguistic perspective. Furthermore, we tried to answer questions related to the perceptive abilities for certain phonetic characteristics of one language with regard to speakers of another, which represents a psycholinguistic approach to the contact of Croatian and Slovene. The following topics were hence explored: segmental differences between the two systems in contact, tonic differences of word accents in Croatian and Slovenian (speech production and perception), the comparison of typical intonational forms of both languages in different communicative situations, verbal fluency and the influence of interference of the first language on the foreign language. Taking into consideration the results of the first project, the objectives of the second project were: a) a comparison between the existing phonological and acoustic description of Croatian and Slovene, with the description based on the spoken material which was analysed within the first project; b) a description of phonetic errors of Slovene speakers whose first language is Croatian and vice versa; c) verbal fluency in the first and foreign language; and d) a comparison between the systems of phonetic errors made by Croatian and Slovene speakers who learn English, French and Spanish.

3 It is interesting to note that the research teams were continuously working on the chosen topics regardless of the fact that there was a two-year gap between the two approved projects. 
As was already stated, from the beginning of this millennium the contrastive research on Croatian and Slovene has been expanded by sociolinguistic and corpus studies, considering both theoretical and practical aspects. For that reason, the preparation of a phonetic activity book was planned for Croatian and Slovene as a foreign/second language, which would compensate for the lack of such books over the last five decades. In fact, except for two manuals, ${ }^{4}$ the phonetic level was present only in certain types of exercises in textbooks of Croatian and Slovene as a foreign/second language. Although the draft of a phonetic activity book was prepared for the Croatian language (cf. Požgaj Hadži et al. 2007: 97-110), unfortunately it remains unpublished. Regarding the Slovene language, $\mathrm{H}$. Tivadar and U. Batista wrote a university textbook entitled Fonetika 1 [Phonetics 1], which is currently in press. Apart from theory, it contains a practical part - conversational exercises (from words, sentences to a text) for beginners and advanced learners, with special attention devoted to the supportive use of music, i.e. songs.

\section{OPEN ISSUES OF STANDARD SLOVENE PRONUNCIATION}

When we consider the relationship between linguistic norms prescribed in normative handbooks, or as Silić (2006: 19) puts it "how one should speak," and language use, i.e. "how one usually speaks," most frequently debated is their constant discrepancy on all language levels. Without any exaggeration, we could describe this relationship as a constant conflict between the two approaches, a traditional (conservative) one which insists on "regulating" linguistic reality and even the language itself, and a liberal one which takes linguistic reality as it is. In this regard, two questions arise: on the one hand, how that relationship is "reflected" in normative handbooks, ${ }^{6}$ and on the other, how speakers of a particular language "manage" to use them. As such, their standard language expression is based on two opposite foundations: the first is a "set of language rules" which they acquire during institutionalized language education, and the second is a "speaker's assessment of whether one or another linguistic fact is common in use" (Matešić 2013: 39). If we question that relationship in the case of Slovene and Croatian, we conclude that an orthoepic level has long been particularly "problematic" in both languages.

Regarding the orthoepic level, we should emphasize the research by R. Šuštaršič in which he often refers to the relationship between the (explicit) norm and language use, where the usage can be seen as a "parallel" norm, which has not yet been codified due to a variety of reasons, not necessarily linguistic ones (Matešić 2013:

4 Here we refer to a monograph Slovensko pravorečje [Slovene Orthoephy] by M. Rupel published in 1946 in Ljubljana and a course book for learning pronunciation Srpsko-hrvatski jezik [SerboCroatian Language] by S. Ivšić and M. Kravar, published in 1955 in Zagreb.

5 The italics in Silić's quotations are used here by the authors.

6 We draw attention to the work by M. Matešić (2013) on the representation of usage examples in normative handbooks in Croatian: to what extent they become part of the norm (codification), how they are described and what their status is. 
41). The discrepancy between linguistic norms prescribed in normative handbooks and the actual usage was already addressed by Šuštaršič (1993) in his PhD thesis, which deals with sentence intonation in Slovene and English. It focuses on the interdependence of tone and tonicity (positions of the nucleus) and the attitudes of speakers in dialogues by comparing Slovene and English. The results show that the normative handbooks (in particular, the Slovene grammar by Toporišič (2000)) offer too generic and/or inadequate rules without taking into consideration the language use.

Let us consider some open issues of the standard Slovene pronunciation - which is actually the title of one of the papers by Šuštaršič, written and co-authored with H. Tivadar (Tivadar/Šuštaršič 2001). The importance of researching the orthoepic norm lies in the fact that in the second half of the 20th century in Slovenia, after the initial enthusiasm of J. Toporišič, a representative of the Zagreb Phonetic School, experimental phonetic and phonological research was not carried out (especially during 1970s and 1980s). Then, in the 1990s, the research intensified, later to expand internationally in the 21st century ( $c f$. Tivadar 2013). Beyond any doubt, as we have already mentioned, the inability to study phonetics as a linguistic discipline further resulted in, among others, a small number of phoneticians and phonologists, and consequently, a lack of spoken corpora, which are prerequisites for such research studies. Nonetheless, Slovene linguists and grammarians addressed problems of standard pronunciation (e.g. S. Škrabec, M. Rupel, J. Rigler, J. Dular, J. Toporišič), related to normative handbooks: grammars, orthography handbooks, and dictionaries, largely neglecting descriptions based on the spoken corpus. The exception is the above-mentioned monograph by Rupel dedicated to the pronunciation of the standard Slovene language, but published more than 60 years ago (see footnote 4 ).

We agree with Tivadar and Šuštaršič (2001: 119) that it is counterproductive to codify language (both written and spoken) while ignoring linguistic reality (usage), and disregarding descriptions of that reality which are based on examples from the corpora. The current written and spoken norms of the Slovene language do not carefully consider the usage, which the authors exemplify not only on a segmental level, indicating "elkanje" (the pronunciation of $<1>$ as $/ 1 /$ ) and "vekanje" (the pronunciation of $\langle\mathrm{v}\rangle$ as $/ \mathrm{v} /$ ), sibilant voicing, the pronunciation of vowels, etc., but also on a prosodic level, which will be discussed later. The problem lies in the fact that in the relatively small area of Slovenia there coexist numerous accents and dialects, hence the standard Slovene pronunciation is influenced by regional pronunciations. Moreover, there is a conflict between "cultivated" literary expressions and colloquial speech (which, of course, differs from dialect to dialect). For some occasions a strictly regulated standard may sound too "formal," whereas colloquial "folk speech" is sometimes considered too "informal" or it can even characterize a speaker as an uneducated "yokel" (Tivadar/Šuštaršič 2001: 118).

Considering the prosodic level of Slovene, one of the burning questions is related to the two types of accentuation: dynamic and tonemic. While Toporišič's grammar (2004: 63) prefers tonemic accentuation, the Slovene Orthography (2001: §622) states 
that both types of accentuation are equal. ${ }^{7}$ The problem lies in the fact that tonemic accentuation is required in the standard pronunciation, although it is typical only for the central Slovene dialects (in the regions of Dolenjska, Gorenjska and Koroška) and is difficult to acquire in the educational process, since it requires the ability to differentiate between different pitch heights and movements. After all, Slovene speakers acquire tonicity spontaneously and unconsciously in the process of language acquisition (Šuštaršič/Tivadar 2005: 23). According to this, the Slovene grammar prescribes something that is contrary to the actual language use, while the Slovene orthography is "more tolerant and performs the task of uniting speakers more efficiently at the same time not widening the gap between amateurs and 'language experts"" (Tivadar/ Šuštaršič 2001: 118-119).

Tonicity remained a leitmotif in the works of Šuštaršič. With regard to this, Šuštaršič and Tivadar (2005) conducted three research studies on the attitudes of students of the Slovene language at the Faculty of Arts in Ljubljana towards tonicity in the standard language, particularly in public speech (reading the news on radio and television), using the perception test (playing a set of recorded short sentences). The main aims of the research were the following: a) perception of tonemic and non-tonemic intonation considering the dialectal origin; b) the level of acceptability of tonemic intonation in public presentations, in affirmative and interrogative sentences (the first two surveys) and in statements (the third survey); c) the level of acceptability of intentionally incorrect intonation of individual lexical items within intonation units. While the aim of all three surveys was the same - to obtain students' responses regarding the (in) appropriateness of tonemic intonation in public addresses - the methodology varied (the number of students, corpus and scoring system were different). In the third survey only, the authors added a questionnaire about the dialectal origin of the subjects and their attitudes regarding standard language and non-standard dialects. The results showed that $95 \%$ of the subjects were in favour of the standard Slovene pronunciation in public addresses (radio, television). The most surprising were the results about the subjects' attitudes to Slovene dialects; as many as $65 \%$ of the subjects characterised them by using typical stereotypes and referring to them as 'ugly,' 'more beautiful,' 'difficult to understand,' etc., while only 35\% "held the democratic (and scientifically sound) view of 'all dialects being equal"' (Šuštaršič/Tivadar 2005: 26-27). Some generalizations can be suggested regarding the attitudes of the subjects towards tonicity in public addresses and their awareness, i.e. whether they perceive 'misplaced' tonemic accents (the circumflex - a falling tone instead of the acute - a rising-falling tone): a) the circumflex in statements is always marked better than the acute; $b$ ) an 'inappropriate' circumflex in statements is marked better than an 'appropriate' one; c) there is a minimal difference in favour of an 'appropriate' compared to an 'inappropriate' acute in statements; and d) the circumflex in questions has lower marks than in statements, and lower marks than the acute in questions. The authors conclude that the subjects exhibit a low level of awareness of Slovene tonicity, and thus tonicity as an essential

7 The Slovene Orthography, 2001: http://bos.zrc-sazu.si/c/sp/sp2001_pravila.pdf (20 September 2016). 
part of standard Slovene is disregarded, which questions its status as an obligatory part of standard pronunciation (Šuštaršič/Tivadar 2005: 32).

R. Šuštaršič also discusses the problem of tonicity in his paper "Position of the Nucleus in an Intonation Phrase in English and Slovene," which was published in 2010 in the monograph Proizvodnja i percepcija govora [Speech production and perception] honouring D. Horga on the occasion of his 70th birthday (Šuštaršič 2010: 351-362). The paper compares tonicity, i.e. the position of the nucleus (the tonic syllable) in an intonation phrase in English and Slovene, in non-verbal and verbal structures in English and Slovene. The main findings are confirmed and extended by comparing tonicity in the dialogues given in O'Connor and Arnold and in Wells. ${ }^{8}$ The main differences between the two compared languages are observed in wh-questions (nucleus on the wh- word in Slovene but not in English) and sentences in the negative form (nucleus on the negating word in Slovene but not in English).

R. Šuštaršič (2013) explores tonicity in partial questions with the pronoun what (wh-questions) in Slovene, also including examples from the spoken corpus GOS. ${ }^{9}$ In contrast to the traditional explanation in normative handbooks - that partial questions have falling intonation and that the nucleus is on the interrogative pronoun - he believes that the type of discourse (frequent rising intonation in private discourse compared to the public one) should be considered together with participants in communication and the structure of interrogative words.

\section{INSTEAD OF A CONCLUSION}

What can be noticed even from this brief overview of research on the problem of tonicity in the standard Slovene language is the persistent discrepancy between how one should speak, i.e. codification, and how one usually speaks, i.e. usage, which is the issue R. Šuštaršič constantly highlighted. What is also apparent is that he approached his research in an interdisciplinary manner, and that he explored certain problems from different theoretical perspectives by studying them in different ways. He was a researcher whose studies were characterized by solid theoretical foundations and detailed insights into previous research. In addition, Šuštaršič was always able to skilfully incorporate theoretical results into applied ones. Furthermore, a clear and tolerant attitude is evident in his study papers, especially towards numerous open issues of the standard Slovene pronunciation, including "elkanje" or "vekanje," or the place of accent (especially by insisting on the traditional difference between short and long accented vowels). By being sincere, cooperative and open-minded, R. Šuštaršič contributed significantly to the teamwork that was seen in the above-mentioned projects, and was a favourite co-speaker in scientific and professional circles, as well as more friendly and informal ones.

8 Šuštaršič cites Intonation of Colloquial English (1973) by J. O’Connor and G. F. Arnold and English Intonation: An Introduction (2006) by J. C. Wells.

9 GOS - the corpus of spoken Slovene: www.korpus-gos.net. 


\section{References}

FILIPOVIĆ, Rudolf (ed.) (1985) Chapters in Serbo-Croatian-English Contrastive Grammar. Zagreb: Institute of Linguistics, Faculty of Philosophy, University of Zagreb.

FILIPOVIĆ, Rudolf/Maja BRATANIĆ (eds) (1990) Languages in Contact of the 12th International Congress of Anthropological and Ethnological Sciences. Zagreb: Institute of Linguistics, Faculty of Philosophy, University of Zagreb.

IVIR, Vladimir/Damir KALOGJERA (1991) Languages in Contact and Contrast: Essays in Contact Linguistics. Berlin-New York: Mouton de Gruyter.

MATEŠIĆ, Mihaela (2013) "Odraz jezične uporabe u normativnim priručnicima hrvatskoga jezika.” In: B. Kryźan-Stanojević (ed.), Javni jezik kao poligon jezičnih eksperimenata. Zagreb: Sredna Europa, 39-51.

POŽGAJ HADŽI, Vesna (2002) Hrvaščina in slovenščina v stiku / Hrvatski i slovenski $u$ kontaktu. Ljubljana: Znanstveni inštitut Filozofske fakultete.

POŽGAJ HADŽI, Vesna et al. (2007) Hrvatski izvana. Zagreb: Školska knjiga.

POŽGAJ HADŽI, Vesna/Tatjana BALAŽIC BULC (2012) "Hrvatski i slovenski: prikaz međusobnih odnosa." In: V. Požgaj Hadži et al., Izazovi kontrastivne lingvistike. Ljubljana: Znanstvena založba Filozofske fakultete, 15-23.

SILIĆ, Josip (2006) Funkconalni stilovi hrvatskoga jezika. Zagreb: Disput.

ŠUŠTARŠIČ, Rastislav (1993) Kontrastivna analiza angleške in slovenske stavčne intonacije: doktorska disertacija. Ljubljana: Filozofska fakulteta UL.

ŠUŠTARŠIČ, Rastislav/Hotimir TIVADAR (2005) "Perception of Tonemicity in Standard Slovene" Govor 22/1, 23-35.

ŠUŠTARŠIČ, Rastislav (2010) "Position of the Nucleus in an Intonation Phrase in English and Slovene." In: V. Mildner/M. Liker (eds), Proizvodnja i percepcija govora: [profesoru Damiru Horgi povodom njegovog sedamdesetog rođendana]. Zagreb: FF press, 351-362.

ŠUŠTARŠIČ, Rastislav (2013) “Tonski potek in mesto jedra v dopolnjevalnih vprašanjih v slovenščini: ponazoritev s primeri iz govornega korpusa Gos (vprašanja z zaimkom kaj).” In: H. Tivadar (ed.), Aktualna vprašanja slovanske fonetike. Ljubljana: Znanstvena založba Filozofske fakultete, 25-33.

TIVADAR, Hotimir/Rastislav ŠUŠTARŠIČ (2001) "Otvorena pitanja standardnoga slovenskog izgovora." Govor 18/2, 113-122.

TIVADAR, Hotimir (2013) "Slovensko-slovansko fonetično raziskovanje." In: H. Tivadar (ed.), Aktualna vprašanja slovanske fonetike. Ljubljana: Znanstvena založba Filozofske fakultete, 35-42.

TOPORIŠIČ, Jože (2000, 2004) Slovenska slovnica. Maribor: Založba Obzorja. 


\section{Abstract \\ RASTISLAV ŠUŠTARŠIČ AND CURRENT ISSUES \\ OF STANDARD SLOVENE LANGUAGE}

By studying languages in contact, we can observe one language while revealing hidden features of another. This was the original idea of the two Slovene-Croatian phonetic and phonological bilateral projects, which connected various Slovene and Croatian phonologists. This paper highlights the work of Rastislav Šuštaršič, who continued his contrastive research of English and Slovene in contact within these projects. Several open issues of the Slovene standard language were also at the centre of his research interests, including the issue of tonemic accent in Slovene, which he studied mainly in collaboration with $\mathrm{H}$. Tivadar. The findings of their works underlined a gap between the explicit norm and language use, which future codifiers of the Slovene standard language should take into consideration.

Keywords: contrastive linguistics, English and Slovene in contact, phonetics, phonology, tonemic accent

\section{Povzetek \\ RASTISLAV ŠUŠTARŠIČ IN SODOBNA VPRAŠANJA STANDARDNE SLOVENŠČINE}

Študij jezikov v stiku nam omogoča opazovanje enega jezika in hkratno razkrivanje skritih lastnosti drugega. To je bila tudi izvirna zamisel, na kateri sta temeljila dva slovensko-hrvaška fonetična in fonološka bilateralna projekta, ki sta združila več slovenskih in hrvaških fonologov. Prispevek izpostavi delo Rastislava Šuštaršiča, katerega kontrastivne raziskave angleščine in slovenščine so povezane s tema projektoma. V svojem raziskovalnem delu se je loteval tudi različnih odprtih vprašanj standardne slovenščine, med katerimi je tonemsko naglaševanje (pri tem je sodeloval predvsem $\mathrm{s}$ $\mathrm{H}$. Tivadarjem). Rezultati teh študij so osvetlili vrzeli med predpisanim standardom in jezikovno rabo, ki bi jih morali upoštevati tudi pri določanju jezikovnih standardov v prihodnosti.

Ključne besede: kontrastivno jezikoslovje, angleščina in slovenščina v stiku, fonetika, fonologija, tonemsko naglaševanje 